\title{
Hanna KOWALSKA-STUS
}

Jagiellonian University in Kraków

kowalska.hanna@gmail.com

\section{THE REPUBLIC OF POLAND AT THE CROSSROADS OF TWO CULTURES}

ABSTRACT The boundary of the Latin and Orthodox Church in the Piast times was a political border. These two boundaries fostered intensification of cultural differences. Christianity shaped the image of man, state, history, esthetic views as well as religious, social and political customs within two distinct cultures: Latin and Hellenic. On the Orthodox side, the patronage of faith in these areas was more unequivocal. In the times of the First Polish Republic both cultures met in one state. The political factor dominated in Latin American countries. It dictated the methods of action also to the Church. The conflict that was begun by the reign of Władysław Jagiełło and deepened by Sigismund III. Due to the Union of Brest, it triggered the conflict between Poland, Polish and Lithuanian Ruthenia and as a consequence - Moscow. The adaptation that Ruthenia had undergone in the Republic of Poland had far-reaching political, social, economic and cultural consequences. As a result of Moscow's subsequent consolidation of Ruthenian lands, these processes affected all of these areas in the Moscow State. The conversion that occurred in the Republic of Poland on Ruthenian lands created a foundation for forming Ukrainian identity created by Austria. This fact is perceived in Russia as separatism used in geopolitical interests of many countries, including Poland, against Russia. Jagiellonian Poland that came to existence in the period of confessional tensions in Europe was subjected to internal contradictory cultural trends and political conflicts in the region, whereas Rome made efforts to control Christianity. These circumstances did not create prospects for development of the Republic of Poland.

Key words: Orthodox Church in the Republic of Poland, the Union of Brest, Latin cultural influences 
The boundary of the Latin and Orthodox Church in the Piast times was a political border. These two boundaries fostered intensification of cultural differences. Christianity shaped the image of man, state, history, aesthetic as well as religious views, and social and political customs within two distinct cultures: Latin and Hellenic. On the Orthodox side, the patronage of faith in these areas was more unequivocal. In the times of the First Polish Republic both cultures met in one state. The political factor dominated in Latin American countries. It dictated the methods of action also to the Church.

The conflict that begun during the reign of Władystaw Jagiełlo and deepened by Zygmunt III due to the Union of Brest, triggered the conflict between Poland, Polish and Lithuanian Ruthenia and, as a consequence, Moscow. The cultural-confessional adaptation that Ruthenia has undergone in the Republic of Poland had far-reaching political, social, economic and cultural consequences. As a result of Moscow's subsequent consolidation of Ruthenian lands, these processes affected all of these areas in the Muscovite state. The conversion that occurred in the Republic of Poland on Ruthenian lands created a foundation for forming Ukrainian identity which was later created by the Austro-Hungarian Empire. This fact is perceived in Russia as separatism used in geopolitical interests of many countries against Russia, including Poland. The Jagiellonian Commonwealth that came into existence in the period of confessional tensions in Europe was subjected to internal contradictory cultural trends and political conflicts in the region, whereas Rome made efforts to control Christianity. These circumstances did not create prospects for development of the Republic of Poland.

Before the personal union of Poland and Lithuania, Orthodox culture in the Lithuanian state was a dominant culture where most of its territory was occupied by Ruthenian lands. The marriage concluded in 1386 between Queen Jadwiga and the grand Lithuanian Duke Władysław Jagiełło commenced not only the personal union of both states, but also opened a new chapter in the history of the influence of Christian Latin culture on West Ruthenian territories. This situation was conducive to shifting the boundary of Latin culture to the east. The Ferrara-Florence Union (1439) between Rome and Constantinople, which was under pressure from the Turkish invasion, had influenced the process. Due to the fact that the union was closely linked to political events, it had no permanent effect. ${ }^{1}$ Rome did not offer the promised help to Constantinople and the Turks eventually occupied it in 1453. Moscow did not acknowledge the union at all and after the fall of Constantinople it became convinced of its eschatological mission as Rome III. The Republic of Poland had nine Orthodox dioceses within its borders and was not interested in the Council of Florence. Moreover, it did not send deputies to the council, although it was involved in financing of the project.

Despite Moscow's explicitly negative attitude towards the union, Rome reiterated union attempts. Some inspiration was the marriage of Zoe, a niece of the last Byzantine emperor, with a grand Muscovite prince, Ivan III (1472). Zoe was brought up in Rome in a Latin environment. This marriage was conducive to the establishment of

Rev. Edmund Przekop elaborates on it objectively in: Rzym - Konstantynopol. Na drogach podziatu ipojednania, Olsztyn 1987, pp. 67-74. 
diplomatic relations between Moscow and Rome. Muscovite deputies employed artists in Rome to rebuild the Kremlin. Nicholas Schomberg and Bishop of Ferrara (Paulus Centurione) were Roman deputies in Moscow who opted for the union. It was connected with the fact that during the whole sixteenth century Rome did not cease making efforts to organize the anti-Turkish league. As a result, popes offered the royal title to great princes of Moscow. Polish kings opposed that in fear of demands to return West Ruthenian duchies.

Rome encouraged Moscow to join the anti-Turkish alliance, which exposed it to a conflict with the Tartars who were allies to the Ottoman Porte. Moscow had to take this fact into account. On the other hand, it needed an alliance with Rome to mediate in oppressive conflicts with Poland. In 1561, Pope Pius IV sent to Ivan IV a legate with an invitation for the delegation of the Moscow clergy to attend the Council of Trent. The legate was not allowed to pass through the territory of the Republic of Poland and similar situations reoccurred. Only a trip of a Jesuit, Antonio Possevino, who enjoyed the support of Piotr Skarga, was successful. However, the courageous legate's plans concerning Muscovites' education in Rome, establishing schools and printing houses in Moscow were rejected by Tsar Iwan IV.

Until 1458, Ruthenian Orthodox Church, irrespective of its nationality, was subject to the jurisdiction of one archdiocese - Kiev. After that date, the Kiev archdiocese administered the dioceses within the borders of the Republic of Poland and the Muscovite diocese was built for the diocese of the Muscovite state. The Kiev archdiocese included six Orthodox dioceses of the Grand Duchy of Lithuania: Połock, Smoleńsk, Czernihowsk, Turów, Łuck and Włodzimiersk, and three of the Kingdom of Poland: Halicz, Przemyśl and Chełm.

The Polish-Lithuanian Commonwealth experienced internal difficulties arising from the conflict of interest between the two political organizations unified by a personal union. We will omit the broader background of this conflict and focus on the stance that Ruthenia took in the union state. We will particularly pay attention to the changes that began in the then Ruthenian-Orthodox culture under the influence of changing political conditions. Cultural transformation that occurred in Lithuanian-Polish Ruthenia in the sixteenth and seventeenth centuries influenced cultural transformations in Moscow.

When the grand Lithuanian Duke Władysław Jagiełlo signed the personal union with Poland, he was baptized with Pagan Lithuanians who became members of the Roman-Catholic Church since then. However, we must bear in mind that since the Lithuanian expansion to Ruthenian territories in the fourteenth century, the majority of population of this substantial state were Orthodox Ruthenians. Lithuania was influenced by Orthodox-Ruthenian culture and was later Polonized and Latinized. It was manifested in the following aspects: legal and state, political (the Sejm and regional councils, offices and related privileges), administrative (division into provinces and counties, German-styled administration of cities), social, confessional, linguistic, written culture, architecture, painting, literature, education and educational system. These changes were often introduced under coercion. Thus, for example, at the Diet 
of Horodło (1413), it was decided that only those Lithuanian boyars who had adopted Roman Catholicism will have the same privileges as Polish gentry. In 1447, Kazimierz Jagiełlo granted these rights also to the Orthodox princes. However, the Orthodox bishops were not part of the Senate. Serfage of peasants modeled on Poland also began. First, there was a ban on peasants moving to ecclesiastical or princely lands, then they were removed from the princes' courts for the benefit of boyars and noblemen. When a nobleman or a boyar was converted to Catholicism or Protestantism, peasants were forced to change their religion. Boyars and Ruthenian-Lithuanian nobility, in order to gain privileges available to Polish nobility, often abandoned the Orthodox Church and Polonized themselves. ${ }^{2}$ They became users of Latin-Polish culture. The rest of the population remained with the Orthodox tradition. These two social groups, built from the same cultural background, began to move away from each other.

Administrative changes in Lithuania, as before in Polish Ruthenia, also led to the collapse of Ruthenian castles. Traditionally, they were patrimonial and their wealth was dependent on the wealth of farmers and craftsmen. They were integrated with the surrounding villages. The population moved freely between states. Along with Polish domination, this kind of mobility began to vanish. The phenomenon was deepened by the dependence of serfdom. Cities that collapsed because of civilization transformations began to rise and were given German-Magdeburg municipal law. According to the law, cities were managed by the mayor and the councilors, whereas the commune head and town councilors dealt in judging. Urban culture in Polish-Ruthenian and Lithuanian-Ruthenian territories was gradually becoming Latin culture and especially villages remained Orthodox. Cities in the sixteenth and seventeenth centuries were becoming increasingly expansive and began to play an important role in the economy and politics and dominate in the culture. The Orthodox did not usually have representatives in municipal governments so they did not influence the creation of the law. It led to the establishment of a law discriminating against Orthodoxy, such as electing Orthodox parish priests by members of the municipality, among whom there were only Roman Catholics.

In the sixteenth century, primarily in Lithuanian Ruthenia, Lutheranism and Calvinism began to spread. According to Stanislaw Litak, at the end of the sixteenth century there were more Protestant churches in Lithuanian dioceses than Roman Catholic parishes. ${ }^{3}$ The extraordinary popularity of Protestantism in Lithuania might be explained by the hope of the local authorities that it will harmonize the faith in the duchy, unlike Catholicism or the Orthodox Church. The trend was also indicated by the fact that in 1525 the Teutonic Order and its master separated from the Catholic Church. They began to translate Protestant works into Polish, Lithuanian and Ruthe-

2 The Ruthenian-Lithuanian privileges of boyars on controlling peasantry, judiciary and administration were confirmed in the Lithuanian Statute of 1529. This code, written in Ruthenian, Polish and Latin, still contained features of Ruthenian legislation. Each successive version of the statute was made similar to Polish law. Первый литовский статут, Вильнюс 1991; see especially ch. 3, pp. 108-121 and ch. 11, pp. 268-279.

3 S. Litak, Od reformacji do Oświecenia. Kościót katolicki w Polsce nowożytnej, Lublin 1994, pp. 40-46. 
nian languages. Barbara Radziwiłł's cousin, Rev. Nicholas Radziwiłł 'the Black', who studied in Geneva, converted to Calvinism. Following his example, Lithuanian and Orthodox Ruthenian gentry and nobility (the Wiśniowieckis, the Chodkiewiczs and the Sapiehas) began to convert to Protestant denominations.

King of the Republic of Poland, Zygmunt August, led a liberal confessional policy which played an important role in terms of the Polish-Lithuanian Union because the Jagiellonian dynasty was expiring along with the personal union. The king saved the union thanks to the definitive cancellation (1563) of provisions of the Union of Horodło (1413) which forbade access to government posts to Orthodox nobility and boyars. However, the decision of Zygmunt August did not include the Orthodox hierarchs. ${ }^{4}$ The king was then supported by a nobleman, Ruthenian Duke Constantine Ostrogski from the Rurykowicz family, Province Governor of Kiev, and Prince Aleksander Czartoryski from the Giedyminowicz family, Province Governor of Volhynia. They had enormous influence among majority of Ruthenian and Lithuanian nobility. The Diet of Lublin (1569) sealed the political union of the two states. At the same time, the Lublin Union introduced a new division of borders. Poland took back four provinces from Lithuania: Podlachia, Volhynia, Kiev and Bracław. Thus, it took over most of the Orthodox dioceses, which ended a certain stage in the history of the PolishLithuanian Union. It was a time of union coexistence of two states in which Lithuania was Orthodox and Poland Latin-Catholic. Queen Jadwiga took this fact into account since the very beginning of the union and pursued politics in Cracow in a way that enabled to meet religious needs of both Catholics and Orthodox citizens. ${ }^{5}$ The new division of borders created a risk of a religious conflict within the Kingdom of Poland.

However, it must be borne in mind that Zygmunt August's religious liberal policy favored primarily the development of Protestantism which led to various schismatic denominations and heretical sects, especially in Lithuania. Protestants were supported by the Lithuanian noblemen and founded higher education institutions for gentry youth. The reaction of the Catholic Church was building a network of monasteries and Jesuit schools in Lithuania. In 1569, Jesuits commenced dynamic activity in Vilnius. In 1574, a Polish-Lithuanian monastic province of Jesuits was established. As a consequence, the number of Orthodox brotherhoods increased. They soon became centers of Orthodox culture. In the years 1584-1585, near Vilnius and Lviv brotherhoods schools were opened. Exarch of the Ecumenical Patriarch, Metropolitan Arsenius, arrived in Lviv as

The Warsaw Diet (1573) passed a decision on religious freedom. Despite the provisions of the diet, the fate of the Orthodoxy in Lithuania, since the time of personal union, had been largely dependent on the decisions of Polish kings, who had been great Lithuanian Princes at the same time. Zygmunt I the Old, for example, allowed the construction of stone Orthodox churches in Vilnius (1514), against the provisions of the Union of Horodło. At the time, Ruthenian nobility were members of the royal council. At the Diet of Vilnius (1529), gentry demanded to ban Orthodox individuals who served as state officials. At the same time, the Lviv Orthodox Brotherhood complained to the king about the oppression.

5 See also H. Kręt, "Dwór królewski św. Jadwigi i Władysława Jagiełty”, in H. Kowalska, H. Byrska, Rev. A. Bednarz (eds.), Święta Jadwiga królowa. Dziedzictwo i zadania na trzecie tysiąclecie, Kraków 2002, p. 196. 
a lecturer and then went to Moscow, where he received one of the bishops' cathedrals. A printing house was also opened in Vilnius. Soon, a network of brotherhoods with their own schools and printing houses were established in Polish-Lithuanian Ruthenia. They were culture-creating Orthodox centers characteristic of these times. ${ }^{6}$ Jesuits took advantage of this fact and founded their own brotherhoods in this area (1575-1589): the Most Holy Body of Christ, the Blessed Virgin Mary and the Divine Mercy. In the years 1569-1574, there existed Lithuanian Orthodox printing houses of Iwan Fiodorow and Piotr Mścisławiec, which distributed printed liturgical books. At that time in Moscow, printing liturgical books was considered heresy.

The culture specificity of Lithuanian-Polish Ruthenia of that period was tied to the fact that the direction of its development was influenced by Jesuit activists who were called by Rome to counter the spread of Protestantism. They also acted against Orthodoxy in the Republic of Poland. In 1577, Rev. Piotr Skarga published a treatise titled: O jedności Kościota Bożego pod jednym pasterzem i o greckim od tej jedności odstapieniu, w celu uprzedzenia i przekonania narodu ruskiego stuchającego Greków (Suggested Translation: On the unity of the Church of God under one shepherd and on its Greek withdrawal, in order to prejudice and convince Ruthenians that listened to the Greeks). This was a harbinger of the program aiming to incorporate Ruthenian dioceses into Roman jurisdiction which was definitely anti-union in its content. Rev. Piotr Skarga raised a number of dogmatic and canonical charges towards the Orthodox Church. ${ }^{7}$ They also referred to Old Church Slavonic liturgical language. It is significant that the struggle with Orthodox liturgical language was an important element of a prounion polemic of the sixteenth and seventeenth centuries. Iwan Wiszenskij, Zacharij Kopystienskij and Lew Kreuza-Rzewuski participated in the struggle. ${ }^{8}$ In response to the treatise of Rev. Piotr Skarga there appeared a polemical treatise (1588) of an Orthodox priest, Wasilij, from Ostróg: O jednej prawdziwej wierze prawostawnej i o św. powszechnym Kościele apostolskim (Suggested Translation: On One Genuine Orthodox Faith and Holy Universal Apostolic Church).

The first serious impulse triggering an open conflict between Catholics and the Orthodox in the Republic of Poland was the issue of a new liturgical calendar introduced by Pope Gregory XIII (1582). The Pope attempted to persuade the Patriarch of Constantinople, Jeremias II (Tranos), but he did not succeed. The patriarch, in his pastoral

6 Zoja Jaroszewicz-Pieresławcew fully describes the scale of the phenomenon of Uniate and Orthodox Ruthenian printing in Druki cyrylickie z oficyn Wielkiego Księstwa Litewskiego w XVI-XVIII wieku, Olsztyn 2003. Orthodox literature was part of the religious literary war that took place in the seventeenth century on the land belonging to the Commonwealth of Two Nations inhabited by the Orthodox. For a catalog of such publishers see: K. Čepienė, I. Petrauskiene, Vilniaus akademijos spaustuves leidiniai 1576-1805. Bibliografija, Vilnius 1979; M. Ivanovič (ed.), XVII a. Lietuvos lenkiškos knygos. Kontrolinis sarašas, Vilnius 1998.

7 See also A. Jobert, Od Lutra do Mohyty. Polska wobec kryzysu chrześcijaństwa 1517-1648, transl. by E. Sękowska, Warszawa 1994, pp. 234, 248.

8 According to Aleksander Naumow, it was suggested that the Moravian-Pannonian mission of Cyryl and Metody, who were treated as supporters of the union, had Roman nature. See also idem, Domus divisa. Studia nad literaturą ruską w I Rzeczypospolitej, Kraków 2002, p. 152. 
letter, called upon the faithful to follow the traditional calendar. In the Diocese of Lviv, Catholic Archbishop Dmitri Sulikowski ordered to close Orthodox churches at Christmas of 1583 due to the rejection of the new calendar by the Orthodox.9

The situation was exacerbated by the reign of Zygmunt III Vasa, who sought to submit Christians in the Republic of Poland to the jurisdiction of Rome, like the Habsburgs in Spain, Austria, Hungary and the Czech Republic. With such a large number of purely Orthodox dioceses and the then gentry parliamentarism, the plan was doomed to fail. In this context, efforts to succeed to the Moscow throne could not have been successful either. Only the internal Muscovite Time of Troubles strengthened the position of the Republic of Poland in the conflict with Moscow.

With respect to Orthodox dioceses within the borders of the Republic of Poland, there was a practice similar to that of Roman-Catholic dioceses. Bishops were not chosen by the Council, according to the Canon Law of the Orthodox Church, but appointed by the king. They were often seculars rewarded with dioceses for political merits. These people were ordained bishops or administrators of the diocese, appointing other ordained bishops to be their successors. An example may be the nomination of Metropolitan Onisifor (Diewoczka), who received an archdiocese without being a clergyman. The chief initiator of the union with the Roman Church, a bishop of Włodzimierz Wołyński, Adam Pociej (1593) had a similar biography - he was a senator and a castellan of Brest. When he was young, he studied at the Calvinist school where he left Orthodoxy, but returned to it in adulthood. He was a widower when he received a diocese on recommendation of Province Governor of Kiev, Duke Konstanty Ostrogski. He renounced secular offices, made monastic vows with the name of Hipacy and was ordained priest and bishop. Ostrogski, the then union advocate, perceived this experienced politician and educated man, who knew Latin, as his assistant.

Actions of bishops on the union renewal were implicit, which was in contradiction with the Orthodox tradition in which the community of the faithful decided on important matters of the Church. Thus, it is not surprising that Duke Konstanty Ostrogski protested in spite of his attachment to the union idea. In June 1595, he sent letters stigmatizing bishops' behavior to the clergy and the faithful of all dioceses. ${ }^{10}$ Biased actions of several bishops of the Republic of Poland, aiming at the renewal of the church union, outraged the Province Governor of Kiev. The duke wanted a union, but not without participation of the whole Eastern Church, and especially Patriarch of Constantinople.

The duke's letter evoked various reactions and aroused strong opposition against the Orthodox hierarchy of the Republic of Poland. Orthodox brotherhoods organized protests in cities. The uprising of a Cossack hetman, Siemion Nalewajko, which broke out in 1595 and embraced peasantry and bourgeoisie, was the first manifestation of

9 In 1584, Stefan Batory published a decree on non-pressuring the Orthodox to introduce the new calendar.

10 “1595 г. июня 24. Окружное послание воеводы князя Константина Острожского православному духовенству и мирянам”, in В. Теплова, З. Зуева (eds.), Уния в документах, Минск 1997 (later: УА), doc. no. 12 , p. 98. 
Cossack solidarity with anti-union Orthodox Church in the Republic of Poland. ${ }^{11}$ In response to the opposition to the proposed union, bishops threatened to excommunicate everyone who did not want to join it. ${ }^{12}$ In the same year, bishops: Hipacy Pociej and Cyryl Terlecki went to Rome where during a solemn liturgy on December 23 the Ferrara-Florence Union was renewed. The union was not supposed to operate under the rules developed by Ruthenian bishops, but in accordance with provisions of Council of Ferrara-Florence supplemented by provisions of the Council of Trent.

In 1596, Metropolitan Michał Rahoza summoned a synod in Brest to ratify the union. One of the pope's representatives in the synod was Rev. Piotr Skarga. ${ }^{13}$ To maintain order, King Zygmunt III delegated, among others, the great Chancellor Lew Sapieha, a Roman Catholic of Orthodox birth, who was a Protestant until recently. ${ }^{14}$ Emissaries of the Eastern Patriarchs who arrived at the synod were: Nicefor (Kantakuzen), ${ }^{15}$ representative of Patriarch of Constantinople and Cyryl (Lukaris), ${ }^{16}$ the emissary of Patriarch of Alexandria. A delegation of monks from Saint Mount Athos and Belgrade Metropolitan Luka also arrived. This delegation was not allowed to join the debate due to the order of King Zygmunt III Vasa who forbade foreigners to attend the synod. Consequently, the opponents of the union gathered separately under Nicefor's leadership and were accompanied by bishops: Gedeon of Lviv and Michaił of Przemyśl, delegations and lay faithful, which was part of tradition of the Orthodox councils. Members of the synod condemned the union and the bishops who signed it were deprived of offices. The Patriarch of Aleksandria (administrator of Patriarchate of Constantinople since 1597), Melecjusz (Pigas), recognized this act as valid and appointed his exarchs in the Republic of Poland: Duke Konstanty Ostrogski, Lviv Bishop Gedeon (Bałaban) and Cyryl (Lukaris). Kiev Metropolitan Michaił (Rahoza) imposed excommunication on the opponents of the union. King Zygmunt III approved the union. In 1597, the court sentenced Patriarch Nicefor who was accused of spying for Turkey and imprisoned in Malbork where he died two years later. ${ }^{17}$

11 Nalewajko was executed in Warsaw in 1597. It is significant that historians interpret Cossacks' uprisings solely in a social and political context. See also W. Serczyk, Historia Ukrainy, $2^{\text {nd }}$ ed., Wroctaw 1990, pp. 74-76.

12 “1595 г. Соборная грамота православных епископов...”, in УА, doc. no. 19, pp. 111-112.

13 J. Tretiak, Piotr Skarga w dziejach i literaturze Unii Brzeskiej, Kraków 1912.

14 Lew Sapieha's biography is typical of those times and what may be astonishing, apart from numerous conversions, is his political commitment. During the Election Sejm, he was supportive of the candidacy of Fiodor Iwanowicz, son of Ivan the Terrible. When Zygmunt III succeeded to the throne, he acted in favor of the king's marriage to Ksenia Godunówna.

15 In 1595, Nicefor participated in the Synod of Jassy in Moldova, during which the Orthodox Church of Moldova rejected Rome's proposal to renew the Ferrara-Florence Union. He was an exarch of Patriarch Jeremiasz II Tranos in Moldova and the Republic of Poland, who erected Patriarchate in Moscow (1589) and was his close associate. He studied and lectured in Padua and was friends with Chancellor Jan Zamojski and Konstanty Ostrogski, Province Governor of Kiev.

16 Then, he became Patriarch of Alexandria and Constantinople.

17 In 2001, Nicefor was canonized as a martyr by Władimir Sabodan, the Metropolitan of Kiev and the whole Ukraine, with the blessing of Patriarch of Constantinople. 
Despite the official accession of Kiev archdiocese to the union with Rome, the Orthodox hierarchs were not admitted to the Senate. It is significant that at the parliamentary session in 1597, Volhynian gentry (especially deputy Damian Hulewicz) demanded the dismissal of the Uniate hierarchs and ultimately the Sejm did not ratify the union. During the Sejm session in 1606, the Orthodox gentry demanded liquidation of the union.

Accidents involving enforcement of the union by hierarchs of the Uniate Church played a crucial role for further development of Orthodox culture in the Republic of Poland. They tried to control the most important centers of Orthodoxy against the will of the faithful. In 1598, they failed to take over the Kiev Pieczersk Lavra which is also the cradle of Ruthenian monasticism and culture. Many conflicts began to arise during attempts to take over temples, monasteries and cemeteries. Jesuits took active part in creation of the Uniate Church consisting of hierarchs but without the faithful. These facts contributed to the establishment of a confederation of magnates and Orthodox and Protestant gentry in Vilnius (1599), on the initiative of Duke Konstanty Ostrogski, in order to oppose Catholic expansion in the Republic of Poland. The confederates intended to enforce the current law and prevent persecution and religious wars. Signatories of the document were: the Ostrogskis, the Wiśniowieckis, Bishop Atanazy Puzyna, the Radziwiłłs, Rafał Leszczyński, Piotr Zborowski (Province Governor of Sandomierz), Mikołaj Naruszewicz and Jan Firlej (Province Governor of Cracow). Among them were province governors, castellans, chamberlains, judges, district governors, dukes and knights. ${ }^{18}$ In the same year Metropolitan Michaił (Rahoza), a hierarch who was not too actively involved in the union, died. Zygmunt III appointed Bishop Hipacy (Pociej) in his place. He was one of the most zealous initiators of the union.

On March 16, 1600, Zygmunt III handed over all the rights to Uniate clergy that were previously granted to the Orthodox..$^{19}$ Another royal document ordered the magistrate in Mohylew to bring to justice a brotherhood which did not want to submit to the Uniate metropolitan. ${ }^{20}$ In 1602 , the king announced an order to expel an archimandrite of Supraśl monastery, Iłarion (Massalski), for refusing obedience to Metropolitan Hipacy (Pociej). ${ }^{21}$ At the same time, Uniate bishops were sued and accused of unlawful actions. In 1601, a Uniate seminary was opened in Vilnius Monastery of the Holy Spirit which was previously associated with the Orthodox Brotherhood. Metropolitan Hipacy (Pociej), during his visit in Lviv in 1604, anathematized all the Orthodox faithful of the city after a dispute with an anti-union bishop, Gedeon. At that time, the Lviv

18 “1599 г. Акт конфедерации заключенный в Вильно...”, in УА, doc. no. 106, pp. 300-307.

19 “1600 г. марта 16. Жалованная королевская грамота униатскому духовенству о предоставлении ему всех прав и преимуществ, которыми ранее пользовалось православное духовенство”, in $У Д$, doc. no. 38, pp. 152-154.

20 “1601 г. августа 7. Грамота короля Сигизмунда III магистрату и православному братству Могикева...”, in УА, doc. no. 39, pp. 154-155.

21 “1602 г. января 19. Окружная королевская грамота об изгнании из государства архимандрита Супрасльского православного монастыря Илмариона Массальского за неповиновение его Киевскому митрополиту Ипатию Потею..., in УА, doc. no. 40, pp. 156-175. 
bishop substituted for an Orthodox metropolitan of the Republic of Poland, non-existent outside the union. In the following year, Zygmunt III granted Bishop Hipacy administrative authority over all the Orthodox sacred locations in Lithuania and Poland and entrusted him with control over the ecclesiastical court for the Orthodox. Taking over Orthodox temples in Vilnius by Bishop Hipacy triggered religious riot in the years 1608-1609. The following year, Cossacks protested in Kiev. In 1610, the diocese of Przemyśl was taken back from the Orthodox. The death of Bishop Gedeon (1607) and Duke Constantine Ostrogski (1608), Province Governor of Kiev, worsened the situation of the Orthodox Church, despite the fact that the Sejm passed a resolution on conferring the rights to the followers of the confession. After sealing the Orthodox churches in 1625 in Kiev, there were Cossack protests.

The most difficult issue of this conflict was the monastic aspect. Monasticism, which came into existence among Egyptian Greeks and developed in the cenobitic tradition of Cappadocia, played an extraordinary role in Orthodoxy. Fathers of the Church, who came from monasteries, contributed to the establishment of dogmas of faith. Hierarchs were chosen out of the priors of significant Orthodox monasteries. Christian anthropology was developed in the monasteries. Ruthenian Orthodox Church also owes its development to monasteries. Thus, all changes in the Church were fateful for the convent. That was also the case with the Union of Brest. Monasteries remained anti-union bastions. Therefore, in 1596, Metropolitan Michaił (Rahoza) and union bishops dismissed and excommunicated the archimandrite of the Kiev Pieczersk Lavra, Nikifor (Tur). ${ }^{22}$ At the same time, the Uniate hierarchs issued a letter addressed to the Orthodox clergy and the faithful announcing deprivation of offices and anathematizing the Bishop of Przemyśl and Lviv, as well as two archimandrites, one hegumen and numerous clerics. ${ }^{23}$

In the history of the Uniate-Orthodox conflict, attempts to create Uniate monasticism played a significant role. Two monks were important characters here - Jozafat (Kuncewicz) and Józef (Rutskij). They were both monks of the only Uniate monastery in Vilnius, the Holy Trinity Monastery. The monastery was previously the seat of an anti-union brotherhood, which, after taking back all Orthodox locations (1609) due to Uniate metropolitan's administration, transferred its seat to the new and the only Orthodox church in Vilnius, the Church of the Holy Spirit.

Another important struggle involved the Supraśl monastery in Podlasie. It took place between the founders and the Uniates. Krzysztof Chodkiewicz ${ }^{24}$ played an important role at this point. He had been fighting with Uniate Metropolitan Józef (Rutskij) before judicial tribunals (since 1631) to obtain dominance over the monastery. Finally,

22 “1596 г. октября 9. Соборная грамота киевсеого митрополита Михаика Рагозы и православных епископов принявших унию...”, in УА, doc. no. 32, pp. 141-142.

23 “1596 г. октября 10. Окружная соборная грамота киевсеого митрополита Михаика Рагозы и православных епископов принявших унию...”, in УА, doc. no. 33, p. 144.

24 Krzysztof's ancestor, Province Governor of Nowogród and Lithuanian Marshal, Aleksander Chodkiewicz, together with Smoleńsk Archbishop, Józef (Sołtan), founded the Supraśl Lavra (1498). The monastery had a well-equipped library. 
the royal court granted control to the metropolitan. In 1635, the monastery was forced to adopt the Basilian (Uniate) rule. Shortly afterwards, the second important center of Orthodox culture became less significant than the Kiev Pieczersk Lavra. ${ }^{25}$

Metropolitan Józef (Rutskij), who played the greatest role in taking away monasteries from the Orthodox, came from a Calvinist family himself. Although he was baptized in the Orthodox Church, ${ }^{26}$ he first converted to Calvinism and then to Roman Catholicism in order to start education in a Greek college in Rome and pledge an oath of allegiance to the union. Previously, he was educated at the Calvinist College, at the University of Prague in Würzburg. If it were not for the Union of Brest, he would probably have become a Catholic. His doubts were dispelled by Jesuit, Paul Boksza, who gave him a letter of recommendation to the Greek college in Rome. Then, he faced with Orthodoxy on a theological level for the first time. Being there, he studied ecclesiological differences and polemic literature for seven years. After twelve years of absence he returned to Lithuania. Initially, he worked as a teacher at the Uniate college under the supervision of Metropolitan Hipacy's Roman advisor, Piotr Arkadiusz. Under the rule of Dymitr Samozwaniec in Moscow, Metropolitan Hipacy sent there Józef (Rutskij) as a missionary, but he quickly returned and began to organize the Uniate monasticism. For this purpose, he was assisted by the pope, who sent some Discalced Carmelites to Vilnius. Jobert points out that they took the Greek Rite and, together with Józef (Rutskij), reformed the Holy Trinity Monastery. ${ }^{27}$ When the archimandrite Samuel (Sienczyłło) began to oppose new orders, Metropolitan Hipacy replaced him with Józef (Rutskij). Monks were initially under the spiritual care of Jesuits. The monastery was attended predominantly by graduates of Jesuit schools and, when Józef (Rutskij) became a metropolitan, he granted dispensation to the monks in order to allow them to continue their education. The pope's scholars were educated in Rome, Prague and Vienna. Uniate bishops of Łuck, Połock, Smoleńsk and Pińsk came from among them and were appointed in the twenties. They shared Metropolitan Józef's views, assisted in his actions, and their lives resembled his biography.

In 1617, the metropolitan founded a monastery Congregation of Basilians of the Holy Trinity which was modeled on the Catholic Church. The statute of the congregation did not reject the traditional ascetic rule, whereas in landed affairs it set similar goals to those of the Society of Jesus. Rutskij was a general of the congregation. Unlike the Orthodox tradition, special assemblies for novices were formed and organized by Jesuits.

Although Józef (Rutskij) wanted Carmelites to help in organizing Uniate monasteries and the pope supported this stance, nobody in the Republic of Poland was interested in this mission. Therefore, this duty fell to Jesuits. It was the beginning of Uniate

25 See also P. Chomik, Kult ikon Matki Bożej w Wielkim Księstwie Litewskim w XVI-XVIII wieku, Białystok 2003, pp. 59-64.

26 Józef's ancestors, Rutskije Wieljaminowy, came from a Muscovite family which had served the Muscovite court for a very long time.

27 A. Jobert, Od Lutra do Mohyty..., p. 266. 
monasticism in which the monasteries were called Basilian, from the name of a Greek author of the monastic rule of the fourth century, Saint Basil, Bishop of Caesarea in Cappadocia. However, the Uniates did not succeed in developing monastic life. From a letter of a papal nuncio, Cosimo de Torres (1622), we find out that there were thirteen Basilian monasteries in which there were only two hundred monks, whereas in Kiev there were eight hundred monks who lived only in one monastery. The Orthodox had more monasteries. The Uniates did not have a single monastery in the dioceses of Przemyśl and Chełm. The nuncio emphasizes that many Uniate monasteries were empty. ${ }^{28}$ The role of monasteries in the Ruthenian Orthodox Church is also confirmed by an incident that occurred in 1638, when the religious situation in the Republic of Poland improved after Zygmunt III's death. At that time, the rumor was that Metropolitan Piotr (Mogiła) intended to join the union. Then, a mass exodus of monks arriving in Moscow began.

Metropolitan Józef (Rutskij), who was not brought up in the spirit of Orthodox tradition and came into contact with Protestant understanding of Christianity at his family home, was undoubtedly influenced by education. At the same time, he was an idealistic man, and this is why he devoted himself to the mission of building the Uniate Church. What he considered the most important and what was the direction of development of this Church was education. A similar goal in the confrontation with Protestantism was set by Jesuits whose activity became a model for the Uniates. However, Metropolitan Józef's goals did not bring the faithful to the Uniate Church. The union was joined by Ruthenian hierarchy, mostly for non-ecclesiological reasons, and some gentry youth. The metropolitan had great difficulty in raising funds for the Uniate seminary. Therefore, Orthodox gentry youth were educated in Jesuit or Calvinist colleges and often converted to these denominations.

Jozafat (Kuncewicz), a friend of Metropolitan Józef from monastic times and a member of the Polock Cathedral, became convinced of aversion of the faithful towards the union. Because the faithful of his diocese boycotted the union, he closed all Orthodox churches in Mohylew, Łuck and Orsza (1617-1619), and afterwards in Witebsk and Połock (1621). In 1621, when Patriarch of Jerusalem, Teofanes, arrived in Kiev, the faithful hoped that the bishop would attend the convened synod. When it did not happen, the Orthodox finally refused to obey the bishop. As a result, the hierarchy ordered to close cemeteries. Then, outraged Ruthenians invaded the premises of Archbishop of Witebsk and murdered him.

This event was preceded by extensive correspondence consisting of numerous petitions from the faithful, monks and clergy, addressed to the Warsaw Sejm, the Senate and city tribunals, complaining of persecution on the part of Uniate hierarchs. Both sides sued each other. Deputies of the Sejm of Warsaw delivered accusatory speeches. ${ }^{29}$ In petitions we most often read about accusations of religious persecution. ${ }^{30}$ Postula-

\footnotetext{
28 “1622 г. Из донесения папского нунция в Польше Торреса...”, in УД, doc. no. 50, p. 195.

29 See also УА, doc. no. 107-112, pp. 307-327.

30 “1622 г. Жалоба волынских депутатов Варшавскому сейму и сенату...”, in УА, doc. no. 112, p. 326.
} 
tors made Archbishop Jozafat (Kuncewicz) the main culprit, accusing him of closing the temples and persecution of priests, which prevented them from saying mass. $\mathrm{He}$ closed Orthodox cemeteries and ordered to throw out corpses from graves which were buried against his prohibition. ${ }^{31}$

We also find evidence of this conflict in the letter of the great Lithuanian Chancellor, Lew Sapieha, addressed to Archbishop Jozafat. Sapieha, who was a supporter of the union and took part in the Synod of Brest (1596), was shocked by the deeds of the hierarchy. The chancellor accused Jozafat of unreliability in describing the socio-religious situation in Lithuania and inconsistent attitude towards Christian ethics. The chancellor emphasized that since the Republic of Poland did not prohibit Jews and Muslims from owning temples, it could not deny it to the Orthodox. ${ }^{32}$

The only city where the power belonged to the Orthodox was Kiev. This was the case because Cossacks took control of the city under the leadership of a valiant hetman, Piotr Konaszewicz-Sahajdaczny. The Uniate Metropolitan of Kiev stayed mostly in Vilnius. Although Cossacks took part in conquering Moscow alongside both the usurpers, they defended Orthodoxy in the Republic of Poland. Thanks to them, the Orthodox hierarchy of the Republic of Poland could be reborn in Kiev. An important event was the visit of Patriarch of Jerusalem, Teofanes. He was in Moscow in 1519 to participate in enthronization of Patriarch Filaret and then Hetman Konaszewicz invited him to Kiev. The patriarch's arrival was honored with a synod attended by delegates from Poland and Lithuania. The synod was protected by Zaporozhian Cossacks. ${ }^{33}$ In the Kiev Pieczersk Lavra, the patriarch ordained seven bishops and Metropolitan of Kiev and Halicz, Iowa (Borecki), a hegumen of St. Michael's Monastery in Kiev. This fact led to a careless move of Zygmunt III, who proclaimed a universal (1621) on arresting newly ordained hierarchs and accused them of being Turkish spies recruited by an agent of the Turkish sultan who claimed to be Patriarch of Jerusalem. The king discerned a great danger to the Republic of Poland in actions of Patriarch of Jerusalem and ordered to arrest all of them. ${ }^{34}$

31 Ibid., pp. 326-327. Jozafat was murdered in Witebsk. For this reason, the king punished the city by taking away the city charter and liquidating Orthodox churches. The situation lasted until the First Partition.

32 “1622 г. марта 12. Ответ $\Lambda$ ьва Сапеги...”, in УА, doc. no. 114, pp. 329-332. When the archbishop asked the chancellor about his own security, he replied that he was the cause of the threat himself. Archbishop Jozafat Kuncewicz was beatified by Urban VIII in 1843 and canonized in 1867 by Pius IX. The archbishop's relics are connected with a turbulent story. Ultimately, they rested at St. Peter's Basilica in Vatican, whereas his left hand and a ring are located in the Basilica of the Sacred Heart of Jesus in the district of Praga in Warsaw. Uniates wanted to make the relics come back to Połock, which was opposed by the Orthodox Church of Patriarchate of Moscow.

33 When the patriarch was leaving Kiev, Cossacks led him to the border where the hierarch forgave their sin of invading Moscow at the side of Prince Władysław IV. See also B. Петрушко, Православие и католичество на западной Украине, Православие.py, 22 July 2003, at <http://www.pravoslavie. $\mathrm{ru} / 5208 . \mathrm{html}>, 25$ July 2017.

34 “1621 г. Универсал короля Сигизмунда III...”, in УА, doc. no. 48, pp. 190-191. 
The union focused the debate on loyalty of Ruthenians to the state and the king in a new direction. This topic is discussed extensively by Aleksander Naumow in his book Domus divisa. ${ }^{35}$ Opposition to the union, treated as a betrayal in the political sense, provoked a new wave of persecutions in Vilnius and cities of the diocese managed by Archbishop Jozafat. Then, all Cossacks entered the Kiev Brotherhood and Metropolitan Iow called the Synod (1621). At the same time, Uniate Metropolitan Józef (Rutskij) sought to win supporters of the idea of creating a patriarchate for West Ruthenia by raising the status of the Orthodox Church in Roman jurisdiction. Contrary to expectations, the union had fewer and fewer followers. The instructions addressed to the papal nuncio in the Republic of Poland, John the Baptist Lancellotti, show that Uniate dioceses had no faithful. The nuncio also clearly stated that the union was concluded to completely destroy Orthodoxy in the Republic of Poland. ${ }^{36}$ In turn, nuncio Cosimo de Torres informed the pope that repression towards Ruthenians who rebelled against the union should not have been used because they were defended by 60,000 Cossacks who were unimaginably dangerous warriors. ${ }^{37}$ He described the exact map of residence of the 'schismatics' in the Republic of Poland and history of Ferrara-Florence Union, which shows that Rome did not have sufficient knowledge about it.

Zygmunt III's reign was a time of tension between the Orthodox Church, the Uniates and the monarch. It was reflected in numerous peasant and Cossack speeches. However, it should be emphasized that a large group of politicians and clergy of various denominations seeking reconciliation emerged in these difficult times. An important role on the Orthodox side played Pieczersk monastery in Kiev, which, due to numerous donations from Ruthenian magnates, had significant economic power..$^{38}$ This made the archimandrite of the monastery a major political figure. The conciliatory faction had negotiated with the king since 1623 and since 1627 with Piotr (Mogiła), son of a Moldavian hospodar and a friend of magnates of the Republic of Poland. Thanks to this, Piotr received a complex of Pieczersk monasteries and then was appointed Metropolitan of Kiev. These circumstances coincided with a new policy of Rome which sought to bring the Orthodox Church closer to the world in terms of the so-called universal (common) union.

The death of Zygmunt III (1632) raised hopes for defusing conflicts. The Convocation Sejm summarized the period of the past reign and recovery plans were submitted. Orthodox delegates, allied with Protestants, demanded restoration of full rights of the Orthodox Church. The Orthodox gentry, ${ }^{39}$ centered around Piotr (Mogiła), decided to take the chance to negotiate and restore freedom and rights of the Orthodox Church. The demand was to abolish the ban on construction of an Orthodox church,

\footnotetext{
35 A. Naumow, Domus divisa..., pp. 63-75.

36 “1622 г. декабря 14. Из инструкции папскому нунцию в Польше Аанчемлоти...”, in УА, doc. no. 49 , p. 192.

37 “1622 г. Из донесения папского нунция в Польше Торреса...”, in УД, doc. no. 50, p. 196.

38 Архив Юго-Западной России, part 1, vol. 1, Киев 1859, pp. 375-389.

39 Adam Kisiel and Ławrientij Drewinskij played the most important role in this respect.
} 
to abolish the law enabling to conduct religious cases against the Church connected with requisition of property, returning sealed churches, church possessions and all parishes and dioceses. They also demanded a permission to build schools, colleges and printing houses. They required punishment for offense and violence towards the Orthodox. Apart from the petition of gentry and clergy, Cossacks also presented more uncompromising postulates.

Ruthenian deputies did not want to allow the end of the Sejm until Artykuty uspokojenia na rzecz narodu ruskiego wyznania greckiego (Suggested Translation: Articles of Peace for Ruthenian People of Greek Denomination) were passed. It was also crucial that Moscow was besieging Smoleńsk at that time and it was not clear whether Cossacks would join it or not. In this situation, Władysław IV enacted Pacta Conventa, in which he approved the archdiocese, Orthodox dioceses and property rights of the Orthodox Church. He also legalized existing brotherhoods, schools and printing houses. ${ }^{40}$ Despite the protests of a papal nuncio, Bishop Laris Honoriusz Visconti, Uniate bishops and some Catholic hierarchs it was ordered to hand over two dioceses, temples and benefices to the Orthodox. The king offered the Uniates the following choice: either the dispute will be settled amicably, or it will be judged according to old Ruthenian laws which Poland and Lithuania had guaranteed. It was obvious that the second solution would have deprived Uniates of almost everything they owned.

The Metropolitan of Kiev Isaja (Kopinskij) and Ruthenian gentry chose Piotr (Mogiła) for the Election Sejm.

Władysław IV's reign was a time of resolving religious conflicts. The 25-year period of banning the Orthodox Church in the Republic of Poland came to an end. The hierarchs acted illegally for 11 years. At that time, the Kiev archdiocese had six dioceses: Połock-Witebsk, Smoleńsk, Przemyśl, Łuck-Ostróg, Lviv and Mohylew. Only the Metropolitan of Kiev, Iow (Borecki), could stay in his cathedral under cover of Cossack troops until 1625. The other bishops acknowledged King Zygmunt III as worthy of judgment. The union metropolitan, Józef (Rutskij), anathematized Orthodox bishops. Therefore, the newly elected bishops hid in monasteries and secretly administered the dioceses. After assassination of a union bishop, Jozafat (Kuncewicz), and numerous repressions some Orthodox joined the union, including Rector Kasjan (Sakowicz) of the School of Bracka in Kiev, Kiriłł (Trankwillion) and Mieletij (Smotryckij) who was a member of the union until the end of his life. Mieletij found an original solution to a difficult problem which was published in Umowa (Уговоры) treatise. He proposed to create a union Patriarchate of Ruthenia independent of both Constantinople and Rome. Thus, he understood the union not in jurisdictional-ecclesiological but cultural sense.

A completely different situation concerned appointing Metropolitan Piotr (Mogiła; 1632-1647). Aleksy Kartaszow emphasizes that choosing Metropolitan Piotr was not in accordance with Orthodox tradition. No synod or pre-synodal consultations were

40 “1632 г. ноября 1. Грамота Владислава IV, данная православному населению Речи Посполитой...”,

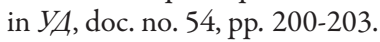


conducted. The metropolitan was elected by a secular body - the Sejm of the Republic of Poland. The Orthodox relied mainly on legalizing the archdiocese due to earlier decisions of Zygmunt III. ${ }^{41}$ As a loyal liege of the Polish king, archimandrite Peter had a great chance to be supported. At the same time, he had long-term plans to create $\mathrm{Pa}$ triarchate of Kiev and a union with Rome under a prior consent of Constantinople. Therefore, this nomination could not meet with an unambiguously positive feedback of Orthodox clergy and monasteries. Some of them moved to Moscow and settled in a monastery in Dunin.

The merit of Metropolitan Piotr was a meticulous reconstruction of holy symbols of Ruthenia which had been dilapidating since the invasion of the Tatars in the thirteenth century. He renewed the Council of St. Sophia and sacrificed it once more. He rose from the ruins one of the first Ruthenian temples, the Church of the Tithes. A marble sarcophagus with the remains of Prince Wlodzimierz was found in the excavations (1635). The relics were transferred to the Uspensky council in the Kiev-Pieczersk monastery and deposited in a silver coffin in a niche on the right side of the altar. The metropolitan transferred some of the relics of St. Włodzimierz to the Uspensky council in the Moscow Kremlin. ${ }^{42} \mathrm{He}$ also rebuilt the Church of the Savior at Berestovo. Restaurants enriched the architectural style of Ruthenia with the so-called baroque of Kiev. It led to aesthetic borrowings on the part of Ruthenian sacred art which followed Poland and Western Europe. The return to Ruthenian style did not take place until the second half of the nineteenth century.

During the reign of Władysław IV and the term of Metropolitan Piotr (Mogiła) in the capital of Kiev, the Orthodox culture in the Republic of Poland was booming. Relations between the Orthodox and Roman Church were correct. Education developed exceptionally well and an Orthodox college was founded in Kiev. Residents of Kiev treated Catholics kindly, which was proved by the fact that a Jesuit college was opened there in 1646. Jesuits were expelled from Ukraine only after Bohdan Chmielnicki's uprising.

It did not mean that Rome was abandoning its attempts to make the Orthodox join its jurisdiction. This is clearly evidenced by the activity of a prominent Capuchin philosopher, Walerian Magni, a missionary of the Congregation for the Propaganda of the Faith in the Czech Republic and the Republic of Poland. Magni's father was a confessor of Władysław IV and his adviser on the matters of the Orthodox Church, Uniates and Protestants. ${ }^{43}$ Magni wanted to act differently than Jesuits and in favor of the union between the churches. He was a master of compromise and knew how to convince others. He contributed to the rise of Artykuty uspokojenia and influenced the Warsaw Confederation and Protestants. This method of action met with a critical as-

41 А. Карташев, Очерки по истории русской Церкви, vol. 2, Москва 1991, p. 281.

42 Before the Second World War, the coffin had been transported to Leningrad where the relics got lost. Moscow relics were kept in the Kremlin museum and were handed over to the Orthodox Church on the eve of the $1000^{\text {th }}$ anniversary of Christianization of Ruthenia. Patriarch of Moscow passed them to the then Rostov and Novocherkassk Metropolitan, Włodzimierz (Sabodan).

43 A. Jobert writes about it in: Od Lutra do Mohyty..., pp. 281-294. 
sessment of the papal nuncio. The pope judged Artykuty uspokojenia to be against the law. However, the committee appointed by the king expressed a negative opinion about the pope's decision. The king proclaimed Artykuty uspokojenia and they were approved by the Sejm despite their subsequent condemnation by the Congregation for the Propaganda of the Faith and the dismissal of Father Magni from the Republic of Poland. Two years later, Father Magni presented the Congregation for the Propaganda of the Faith a union project made by Metropolitan Piotr (Mogiła). He invoked original unity of the Church and assumed that the Orthodox will surrender to papal jurisdiction until Constantinople does not regain freedom. He claimed that the faithful must decide about the union, not the hierarchs. After the death of the metropolitan, his project was discussed during the session of the Sejm in Vilnius in 1647. Ruthenian gentry did not agree to the union without the consent of Patriarch of Constantinople and refused to renounce his authority. Meanwhile, the Congregation demanded that the pope approve Orthodox metropolitans. ${ }^{44}$

The times of Metropolitan Sylwester (Kossow), elected to the capital of Kiev in 1647 after the death of Metropolitan Piotr (Mogiła), were dominated by Bohdan Chmielnicki's uprising. Sylwester (Kossow) and Patriarch of Jerusalem, Paisjusz, staying in Kiev in 1647, gave Bohdan Chmielnicki their blessing before the war with Poland. The Treaty of Zboriv that Chmielnicki and the Republic of Poland reached in 1649 returned the Chelm diocese to the Orthodox Church which gave him an advantage over the union. Orthodox Metropolitan of Kiev received a Senate seat. Only Orthodox gentry was to hold the office in three provinces: Kiev, Bracław and Czernihowsk. Uniate clerics, Jesuits and Jews were removed from the provinces. The agreement survived until the hetman's defeat in 1652 . Then, the Orthodox began to escape to the Muscovite state in a large scale. As a result, Chmielnicki signed a Treaty of Pereyaslav in 1654, making Pridnestrovian Ukraine dependent on Orthodox Muscovite Tsar, Aleksy Michajłowicz. Moscow annexed a part of Lithuanian Ruthenia either. Tsar Aleksy Michajłowicz assigned property rights to the attached dioceses. Metropolitan of Kiev, Sylwester (Kossow), remaining within the jurisdiction of Constantinople, opposed to hand over the archdiocese to Moscow's jurisdiction. Although Ukrainian peasants and Cossacks were defending Orthodoxy, their political interests were often contradictory. The situation of both Ruthenia in the Republic of Poland, the Republic of Poland itself and Lithuania became very complex on many levels: confessional, cultural and political. After concluding the eternal peace between Moscow and the Republic of Poland in 1686, Kiev and Smoleńsk were within the borders of Moscow. Poland committed itself to return the following dioceses to the Orthodox: Mohylew, Łuck, Przemyśl and Lviv. A year later, Eastern patriarchs handed over jurisdiction over the Kiev archdiocese to Patriarch of Moscow. The Orthodox, who remained within the borders of the Republic

44 See also ibid., p. 296. 
of Poland were subject to the jurisdiction of Moscow from then on..$^{45}$ The Republic of Poland provided a guarantee of freedom for the Orthodox living in its territory.

Throughout the sixteenth century and until the end of the seventeenth century, Poland and Lithuania experienced wars with Moscow. Orthodox Ruthenians participated in the wars on the Polish-Lithuanian side. It triggered Moscow's distrust to everything that was associated with them. A Russian historian, Jewgienij Szmurło, argues that the cause of the wars was the desire of both sides to capture Smoleńsk and Kiev as the two cities made it possible to control the strategic Dnieper River. ${ }^{46}$ Internal problems of the Republic of Poland, which was poorly consolidated, not homogenous in terms of ethnicity and religiously divided, made it less and less effective in confrontation with Moscow. Great Ruthenian Princes had never renounced Kiev, emphasizing that it was their wotczina (patrimonium). Year 1686 marked the beginning of Moscow's expansion towards the Republic of Poland to consolidate West Ruthenia. ${ }^{47}$

Władysław IV's religious policy, which aimed at peaceful coexistence of the Orthodox and Uniates, proved to be ineffective. Hostility between the followers of both confessions did not subside. Prerogatives of royal power were too weak to cope with this problem, which in some periods took the form of a local civil war. Bohdan Chmielnicki's rebellion can be used as an example. It was the first major harbinger of secession of these lands from the Republic of Poland and incorporating them into Moscow.

At the same time, gentry democracy was not strong enough to prevent Zygmunt III's decisions on introducing the union and subordinating Orthodox dioceses to Rome. The decision was made without the consent of the General Sejm. Ruthenian gentry could legitimately organize a confederacy against the king. This political system was different from many Western monarchy systems and favored the resurgence of the Orthodox Church. After the period of religious wars, the rulers of the system introduced a principle of cuius regio eius religio which was convenient for them. The first step of Ruthenian gentry was to make the Sejm consider if provisions of the Union of Brest complied with the law. The Orthodox skillfully used elements of the parliamentary system, such as the parliamentary tribune and the right of religious freedom established during the reign of Zygmunt August. The Uniate hierarchy was often judged illegal in order to request liquidation of the union in 1606. The Sejm gave equal rights to both the confessions and demanded mutual respect and obedience to the law. It was a step forward because it deprived Uniates of the right to act on behalf of all the Orthodox and to treat those who refused to accept the union as schismatics. However, it was a purely casuistic solution since, in practice, little changed and the oppression on the part of Uniate hierarchs did not lessen. Despite that fact, the parliamentary tribune

45 Some of the Orthodox were found in Turkey after the Treaty of Buchach (1672). They were handed over to jurisdiction of Patriarch of Constantinople.

46 Е. Шмурло, Курс русской истории, vol. 2: Русь и Аитва, Санкт-Петербург 1999, pp. 360-361.

47 It confirmed the Truce of Andrusovo from 1667. The Republic of Poland renounced: left-bank Ukraine, Kiev, Smoleńsk and Severian territories, Czernihow land, Dorogobuż and Starodub. Moscow offered an equivalent of 730,000 PLN in the form of compensation. The treaty was signed in Lviv by King Jan III Sobieski (1686) in the presence of a group of Russian envoys. 
made it possible to raise the issue. Canonical survival of the Orthodox Church on the territory of the Republic of Poland was possible due to the fact that two bishops did not accede to the union: Bishop of Lviv, Gedeon (Bałaban), who died in 1607, and Bishop of Przemyśl, Michaił (Kopysteński), who died in 1612. The rule-of-law system in the Republic of Poland made it possible for bishops to defend two Orthodox cathedrals despite the pressure of Uniate bishops and the king himself. It enabled to ordain and send priests to dioceses that were managed by Uniate bishops. ${ }^{48}$

The development of the situation within the borders of the Republic of Poland was part of the problem. On a larger scale, it concerned primarily Rome, where a large number of Greeks and hierarchs of the Orthodox Church sheltered after the fall of Constantinople. Initially, popes made sure that Greeks had a guaranteed religious autonomy. According to Rev. Edmund Przekop, the situation changed during the Counter-Reformation..$^{49}$ The Orthodox Church was suspected to be the source of heresy at that time. The papal bull of Pius IV (1564) deprived Greeks of all religious privileges. It referred negatively to the Greek Rite which the pope considered as superstition, heresy, godlessness and sacrilege, like in the case of Holy Communion served to infants immediately after christening. The Orthodox were handed over to the jurisdiction of Latin bishops. Rev. Przekop notes that this fact led to Latinization of the Greek Rite. In the period of Counter-Reformation, Jesuit colleges were also founded in Orthodox areas: Constantinople, Thessalonica, Athens and Smyrna. Studying there, young Greeks converted to Roman Catholicism. Pope Gregory XIII (1572-1585) made contact with Patriarch of Constantinople, Jeremiasz II (Tranos), with a view to the union. His successor, Sixtus V (1585-1590), understood the union as absolute subordination of the ecumenical patriarch. He also decided that decrees of local Orthodox synods will be submitted to Rome for approval. In 1622, the Congregation for the Propaganda of the Faith was constituted. It administered Eastern Catholic communities which were annexed to Roman jurisdiction. Rome established its patriarchates in the East in the times of the Crusades and made no difference between them and traditional patriarchates of the East. However, as Rev. Przekop emphasizes, Rome imposed its legal concept on them over time (the Second Council of Lyon in 1247).

Ecclesiological-law problems were intensified by theological differences. Eastern theology cultivated the monastic-patristic tradition, whereas the Latin world chose scholasticism. Founded on Aristotle's epistemology, Latin theology was a coherent system of definitions and concepts. A theologian of hesychasm, Gregory Palmas, acted against it. Scholasticism concentrated on the interpretation of the Creed, liturgical rite, the cult of Mary and Christ and, above all, it appeared at schools on Orthodox territories which were annexed to Rome. Hesichastic monastic Byzantine Renaissance was also noticeable in other areas outside Roman jurisdiction. What is significant is the history of a Greek college in Rome, founded by Pope Gregory XIII in 1576. The founder's

48 Priests were also ordained by Moldavian bishops.

49 E. Przekop, Rzym - Konstantynopol..., pp. 81-82. 
will was to use Greek language in teaching the Orthodox clerics but, at the beginning of the seventeenth century, complaints were made that learners were taught Latin.

The union on the territory of Poland, Lithuania and Moscow, covered a number of topics. The boundary of Latin and Orthodox Church coincided with the political (state) border. These two boundaries were in favor of deepening cultural differences and increasing the sense of alienation. However, it must be borne in mind that a culture-making factor was faith that shaped metaphysical and anthropological views and religious, social, and political customs. On the Orthodox side, the patronage of faith in these areas was more explicit. However, European civilization was dominated by a political factor in those times. It also dictated methods of action to the Church. This tendency affected culture in Moscow more than anywhere else.

Without diminishing the importance of the dispute between Rome and Constantinople, it should be emphasized that since the sixteenth century European culture had been involved in the Roman-Protestant war. The war was based on an ecclesiological idea. Therefore, it created very strong cultural impulses and, due to them, cultures which represented various Christian denominations gained a very clear and distinct character. Cultural consequences of the endavours of King Zygmunt III and Latin hierarchs' to subdue the Orthodox Church to Rome were linked to fighting against Protestantism on the territory of Lithuanian-Polish Ruthenia. The struggle between Rome and Protestants in Europe lasted for decades and was in favor of creating an abundant arsenal of resources necessary not only for effective polemics, but also for extending influence on another territory. Both Rome and especially Calvinists had an extensive network of schools, publishing houses, printing houses, bookstores and similar tools that served to fight each other and influence the change of cultural and civilization standards in Lithuanian-Polish Ruthenia. The Orthodox were not an isolated group in social or political sense, so the tools became available also to them. For that reason, when the union was approved by a local synod in Brest, there was a dispute between Orthodox and Roman Catholics. The latter were more efficient in administering educational institutions and publishing houses, but the Orthodox were familiar with them either. If it were not for this fundamental dispute within the Latin culture, its development would certainly not have been so unexpectedly dynamic. The impact of Polish culture on the Orthodox environment would also have been different. It would not have affected essential areas of religious tradition. A characteristic bridge between Latin and Byzantine tradition was the return of authority of ancient Greek philosophic epistemology which, according to the Orthodox culture, was overcome in mystical theology of Church Fathers. The dominant Christological element did not make issues of philosophy and moral theology come to the fore, but Christology and anthropology. It guaranteed the advantage of monastery culture over the culture of the Byzantine school. Monasteries in Ruthenian history, unlike Byzantium, were the only culture-making institution.

The Time of Troubles in Muscovite state was the moment when the syndrome of West-European culture moved to the East in the form of an inter-confessional dispute. Even then, some of the Moscow elites, after the reforms of the sixteenth century, thought in a narrow political sense. The opposite side, seeing that Zygmunt III was a representa- 
tive of the pope, began to defend Moscow - the Third Rome - against eschatological destruction. Initially, defenders of the tradition had the upper hand, but their victory was purely political. The culture was gradually transformed and influenced by Lithuanian-Polish Ruthenia as well as the Latinized Greek Orthodox Church. Because the Muscovite culture was solely religious, the process referred primarily to the Church.

During the Polish-Muscovite War, monk Mieletij (Smotrickij), a pupil of the Vilnius Jesuit College, published Threnos (1609) which described persecution of the Orthodox Church in the Republic of Poland. In 1616, the Moscow Synod appealed to the Orthodox people of the Republic of Poland and warned them not to join the union with Roman Church. ${ }^{50}$ The document shows signs of recognition of West-Ruthenian theological-polemic treaties as an entirely canonical argument in the dispute with the Latin Church. Bishops recommended reading Homilia o Antychryście (Казанье об Антихристе) of protoiereus Stefan (Zizanija). It was an interpretation of a homily of Cyril of Jerusalem (the fourth century) presented in the context of contemporary events that referred to introducing the union. The author announced the arrival of Antichrist in the person of the pope who sought to take control of the world by means of a sword. He spread corrupted faith with the help of fake prophets and teachers: Jesuits and Uniates. Philosophy and rhetoric were attributes of Jesuit erudition and tools in the hands of Antichrist to attract the Orthodox to the Latin Church.

It should be assumed that Muscovite hierarchs were not interested in methodology of learning, which was the foundation for polemical arguments, but in the defense of Orthodoxy. Tatiana Oparina argues that the absence of a border between Moscow and the Republic of Poland during the long war in the early seventeenth century was conducive to the spread of Orthodox literature from the Kiev archdiocese. ${ }^{51}$

After the Time of Troubles, sanctification of tradition becomes a dominant indicator which begins to influence social mentality. It indicates marginalization of further influence of the dynamic factor on Ruthenian Orthodox culture which is manifested by the endeavor to transform and exceed earthly existence in hesichastic mysticism. Sanctification causes that reality is perceived as a static norm in the culture. The statichierarchical model of the state is stabilized. This situation has a crucial impact on events in the seventeenth century. It influences the attitude towards cultural and religious impact of Kiev. However, after a short period of triumph of dynamism, when efforts are made to deal with the Time of Troubles, it brings back the state to the structure of the sixteenth century. Until then, the state becomes a superior value. The interpretation of Daniel's prophecy made by monk Filoteus at the beginning of the sixteenth century in the form of the idea of Moscow - the Third Rome will have evolved until that time. The continuation of Byzantine Rome was sanctioned by the council of 1589 when the first Patriarch of Moscow was elected. The patriarch of Constantinople, Jeremiasz II

50 Aктьи, собраннье в библиотеках и архивах Российской империи Археографическою экспедичиею, vol. 3, Санкт-Петербург 1836, no. 327.

51 Т. Опарина, Иван Наседка и полемическое богословие киевской митрополии, Новосибирск 1998, p. 35 . 
(Tranos), spoke about the great Tsardom of Russia and the Third Rome during the enthronement ceremony in Moscow. It is evidenced in a document bearing his signature and seal. Therefore, this title acquired canonical qualities: I wszystka prawda zlata sie $w$ to jedno carstwo, a ty jesteś jedynym carem chrześcijańskim w catym wszechświecie, dla wszystkich chrześcijan ${ }^{52}$ (Suggested Translation: All the truth contributed to one Tsardom and you are the only Christian Tsar all over the universe, for all Christians).

\section{BIBLIOGRAPHY}

Chomik P., Kult ikon Matki Bożej w Wielkim Księstwie Litewskim w XVI-XVIII wieku, Białystok 2003.

Čepienè K., Petrauskienè I., Vilniaus akademijos spaustuves leidiniai 1576-1805. Bibliografija, Vilnius 1979.

Ivanowič M. (ed.), XVII a. Lietuvos lenkiškos knygos. Kontrolinis sarašas, Vilnius 1998.

Jaroszewicz-Pieresławcew Z., Druki cyrylickie z oficyn Wielkiego Księstwa Litewskiego w XVI-XVIII wieku, Olsztyn 2003.

Jobert A., Od Lutra do Mohyty. Polska wobec kryzysu chrześcijaństwa 1517-1648, transl. by E. Sękowska, Warszawa 1994.

Kręt H., "Dwór królewski św. Jadwigi i Władysława Jagiełły", in H. Kowalska, H. Byrska, Rev. A. Bednarz (eds.), Święta Jadwiga królowa. Dziedzictwo i zadania na trzecie tysiąclecie, Kraków 2002.

Litak S., Od reformacji do Oświecenia. Kościót katolicki w Polsce nowożytnej, Lublin 1994.

Narbutienè D., Narbutas S. (eds.), XVII a. Lietuvos lotyniškų knygu sąrašas. Index librorum latinorum Lituaniae saeculi septimi decimi, Vilnius 1998.

Naumow A., Domus divisa. Studia nad literatura ruską w I Rzeczypospolitej, Kraków 2002.

Przekop E., Rzym - Konstantynopol. Na drogach podziatu i pojednania, Olsztyn 1987.

Serczyk W., Historia Ukrainy, $2^{\text {nd }}$ ed., Wrocław 1990.

Tretiak J., Piotr Skarga w dziejach i literaturze Unii Brzeskiej, Kraków 1912.

Актьи, собраннье в библиотеках и архивах Российской империи Археографическою экспедициею, vol. 3, Санкт-Петербург 1836.

Архив Юго-Западной России, part 1, vol. 1, Киев 1859.

Карташев А., Очерки по истории русской Церкви, vol. 2, Москва 1991.

Опарина Т., Иван Наседка и полемическое богословие киевской митрополии, Новосибирск 1998.

Первый литовский статут, Вимьнюс 1991.

Петрушко В., Православие и католичество на западной Украине, Православие.ру, 22 July 2003, at < http://www.pravoslavie.ru/5208.html>.

52 Грамота 1589. As cited in: Н. Синицына, Третий Рим. Истоки и эволюиия русской средневековой концепции (XV-XVI вв.), Москва 1998, p. 302 (transl. by H.K.-S.). 
Синицына Н., Третий Рим. Истоки и эволючия русской средневековой концепции (XV-XVI вв.), Москва 1998.

Тепцова В., Зуева З. (eds.), Уния в документах, Миннск 1997.

Шмуряо Е., Курс русской истории, vol. 2: Русь и Аитва, Санкт-Петербург 1999.

Professor dr hab. Hanna KOWALSKA-STUS - head of the Department of Orthodox-Byzantine Culture at the Jagiellonian University. Her research interests include: Ruthenian-Byzantine culture, Russian emigration literature, history of Russian Orthodox Church, contemporary Russian Orthodox culture. 